Proc. Estonian Acad. Sci. Eng., 2003, 9, 4, 272-280

\title{
Durability of advanced TiC-base cermets
}

\author{
Heinrich Klaasen, Jakob Kübarsepp, and Irina Preis \\ Department of Materials Engineering, Tallinn Technical University, Ehitajate tee 5, 19086 Tallinn, \\ Estonia; jakob@edu.ttu.ee
}

Received 7 July 2003

\begin{abstract}
Mechanical and wear behaviour of some advanced cemented carbides, prospective for metalforming, TiC-base cermets and WC-base hardmetals differing in composition and binder structure have been analysed in a set of tests including durability (blanking performance and fatigue endurance) complemented by SEM. It was found that the blanking performance (durability during blanking of sheet metals) of a cemented carbide is controlled by its adhesive wear resistance and fatigue sensitivity (slope of the Wöhler curve). In respect to blanking performance and fatigue endurance, the advantage of advanced steel-bonded TiC-base cermet over the conventional WCbase hardmetal used in metalforming has been revealed.
\end{abstract}

Key words: cemented carbide, cermet, hardmetal, blanking die, fatigue, wear.

\section{INTRODUCTION}

Application of cemented carbides (hardmetals and cermets) allows the service life of tools and wearing machine parts to be prolonged. These materials are mainly used in service conditions, in which high wear resistance either in abrasive conditions or at elevated temperatures (high speed cutting) is required.

Cemented carbides, particularly cermets, are less used in non-cutting applications owing to the complicated wear conditions in metalforming, when severe wear is accompanied by high stresses of cyclic and impact nature. In such conditions mainly high alloyed tool steels and tungsten carbide base hardmetals (with relatively high binder fraction) have been used with success so far $\left[{ }^{1,2}\right]$.

In the present paper the mechanical and tribological behaviour of some advanced titanium carbide-base cermets with steel binder were investigated in terms of their performance as tool materials for metalforming (blanking) applications and their response as inserts in fatigue and wear experiments $\left.{ }^{3-5}\right]$. 
The performance of these cermets was compared with conventional tungsten carbide hardmetals used for the production of blanking tools (in blanking of the electrotechnical sheet steel). Another important aim was to indentify any correlation between blanking performance and wear mechanism during blanking on one hand and fatigue endurance and wear (adhesive and abrasive-erosion wear) on the other. A few papers devoted to this issue concern mainly tool steels and ceramics for milling, turning, and other cutting operations $\left[{ }^{6,7}\right]$.

\section{MATERIALS AND EXPERIMENTAL PROCEDURE}

\subsection{Materials}

The advanced TiC-base cermets to be tested in terms of their performance as tools for blanking applications (in relation to conventional WC-hardmetal) are presented in Table 1 (the following notations have been used: $d$-grain size, $H R A$ - hardness, $R_{\mathrm{TZ}}$-transverse rupture strength, $R_{\mathrm{c}, 0.1}-$ compression proof stress, $\varepsilon_{\mathrm{p}}$-ultimate plastic strain). The alloys differ in TiC content (60 and $70 \mathrm{wt} \%$ ), composition ( 8 and $14 \mathrm{wt} \% \mathrm{Ni}$ ), and structure (martensite, austenite) of the steel binder.

Mechanical properties (durability characteristics), relevant in metalforming of the TiC-cermets selected, corresponded to those of the conventional (optimal) WC-base hardmetals used in blanking: $H R A \geq 87, R_{\mathrm{c}, 0.1}>2 \mathrm{GPa}$, and $\left.\varepsilon_{\mathrm{p}} R_{\mathrm{TZ}} \geq 28 \mathrm{~J} \mathrm{~cm}^{-3}{ }^{2,3}\right]$.

\subsection{Experimental procedure}

The durability tests were carried out as functional ones, blanking grooves into electrotechnical sheet steel (with hardness $150 \mathrm{HV}$, proof stress $1600 \mathrm{MPa}$, tensile strength $R_{\mathrm{m}}=3200 \mathrm{MPa}$, and thickness of $0.5 \mathrm{~mm}$ ) by means of a 3position die (reinforced with 3 different cemented carbides to be investigated) mounted on an automatic mechanical press (Fig. 1).

Table 1. Structural characteristics and mechanical properties of advanced carbide composites

\begin{tabular}{c|c|c|c|l|c|c|c|c|c}
\hline $\begin{array}{c}\text { No. } \\
\text { of } \\
\text { die }\end{array}$ & Grade & $\begin{array}{c}\text { Carbide type } \\
\text { and content, } \\
\text { wt\% }\end{array}$ & $\begin{array}{c}d, \\
\mu \mathrm{m}\end{array}$ & $\begin{array}{c}\text { Binder } \\
\text { composition and } \\
\text { structure }\end{array}$ & $\begin{array}{c}H R A, \\
\mathrm{HV}\end{array}$ & $\begin{array}{c}R_{\mathrm{TZ}} \\
\mathrm{GPa}\end{array}$ & $\begin{array}{c}R_{\mathrm{c}, 0.1}, \\
\mathrm{GPa}\end{array}$ & $\begin{array}{c}\varepsilon_{\mathrm{p}}, \\
\%\end{array}$ & $\begin{array}{c}\varepsilon_{\mathrm{p}} R_{\mathrm{TZ}}, \\
\mathrm{J} \mathrm{cm}^{-3}\end{array}$ \\
\hline 1 & $\mathrm{H} 15$ & $\mathrm{WC}, 85$ & 2.15 & Co (W) & 87.5 & 2.8 & 2.3 & 1.5 & 39.0 \\
2 & $\mathrm{~T} 60 / 8$ & $\mathrm{TiC}, 60$ & 2.10 & $\begin{array}{l}\text { Fe+8\% Ni steel, } \\
\text { martensite-bainite* }\end{array}$ & 88.0 & 2.2 & 2.1 & 1.4 & 35.5 \\
3 & $\mathrm{~T} 70 / 14$ & $\mathrm{TiC}, 70$ & 2.05 & $\begin{array}{l}\text { Fe+14\%Ni steel, } \\
\text { austenite- } \\
\text { martensite* }\end{array}$ & 88.2 & 2.3 & 2.2 & 1.8 & 40.0 \\
& & & & & & &
\end{tabular}

* Traces of bainite in $\mathrm{Fe}+8 \%$ Ni binder and martensite in $\mathrm{Fe}+14 \% \mathrm{Ni}$ binder. 


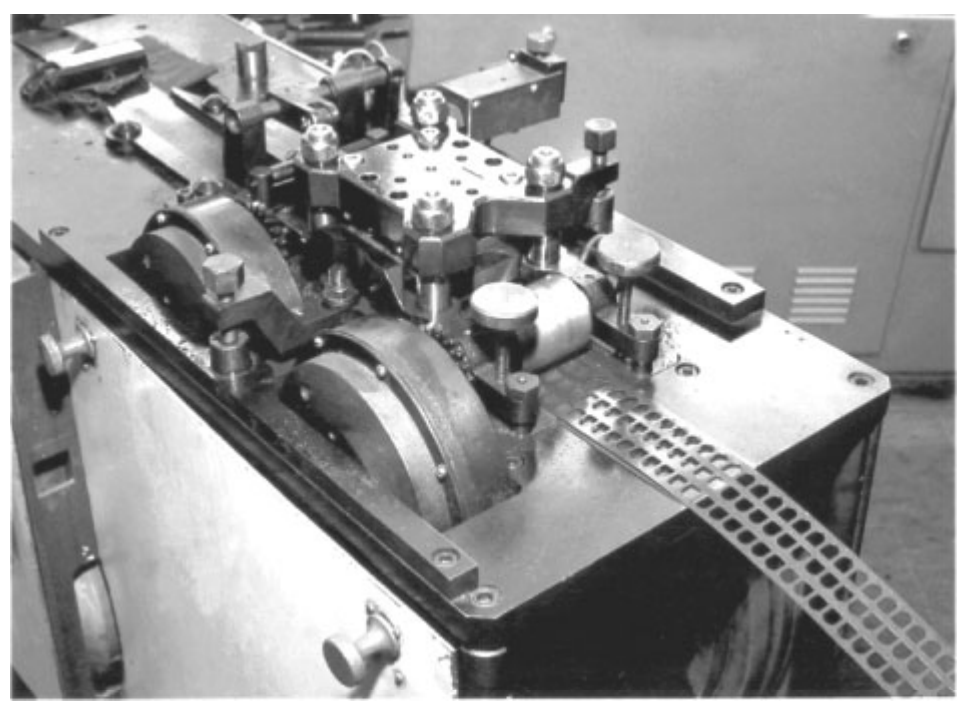

Fig. 1. Durability testing of cemented carbides in three-position die mounted on the automatic mechanical press.

The wear resistance (blanking performance of hardmetal tools - dies) was evaluated by the side wear $\Delta D$ (increase of the die perimeter $D$ ) after intermediate service time $N=0.5 \times 10^{6}$ strokes as $N / \Delta$ (lasting time in strokes per $1 \mathrm{~mm}$ of side wear $\Delta$ ). The intermediate service time $0.5 \times 10^{6}$ corresponded to the time between two consecutive prophylactic sharpenings used by the exploitation of blanking dies $\left[{ }^{2}\right]$. The side wear measure $2 \Delta=\Delta D$ was determined by means of the measuring machine WMM500 at constant environmental conditions (temperature and humidity) as an average of 4-6 measurements.

Abrasive-erosion tests were conducted by means of a centrifugal accelerator $\left[{ }^{8}\right]$. The conditions were as follows: abrasive was quartz sand with particle size $0.1-0.2 \mathrm{~mm}$, jet velocity was $80 \mathrm{~m} \mathrm{~s}^{-1}$, and attack angle $30^{\circ}$. The erosion rate was determined as the specific volumetric wear in cubic millimeters to $1 \mathrm{~kg}$ of abrasive. The relative wear resistance was determined as the ratio of the wear rate of the primary standard material (normalized steel $0.45 \% \mathrm{C}$ ) to the wear rate of the investigated alloy. Four test pieces were analysed. For the probability of $95 \%$, the wear rate confidence interval did not exceed $10 \%$.

A special method for adhesive wear tests (elaborated for the evaluation of blanking performance), turning of mild steel $(170 \mathrm{HV})$ at low speed $\left(v<12 \mathrm{~m} \mathrm{~min}^{-1}\right)$ when adhesive failure prevails, was used $\left[{ }^{8}\right]$. The wear rate was determined as the length of the wear land $h$ at the tool (specimen) nose after specific length of the cutting path $L$. The adhesive wear resistance $L / h$ was evaluated as the length of the cutting path $L$ per $1 \mathrm{~mm}$ length of the wear land $h\left[^{8}\right]$. Confidence interval of the wear resistance did not exceed $10 \%$ when the number of test pieces was at least three. 
The mechanical properties of cemented carbides were estimated by the transverse rupture strength $R_{\mathrm{TZ}}$ in accordance with ISO332 (specimen $\mathrm{B}$ ). The fatigue tests were carried out with bending (fatigue of specimens $5 \times 5 \times 15 \mathrm{~mm}$ under repeated transverse bending load) $\left[^{9}\right]$.

The durability, wear, and mechanical tests were complement by SEM investigations performed on a scanning electron microscope JEOL JSM 840A.

\section{RESULTS AND DISCUSSION}

In Figs. 2 and 3 the results of testing of advanced titanium carbide base cermets (Table 1), elaborated for metalforming applications, are presented $\left[{ }^{4}\right]$.

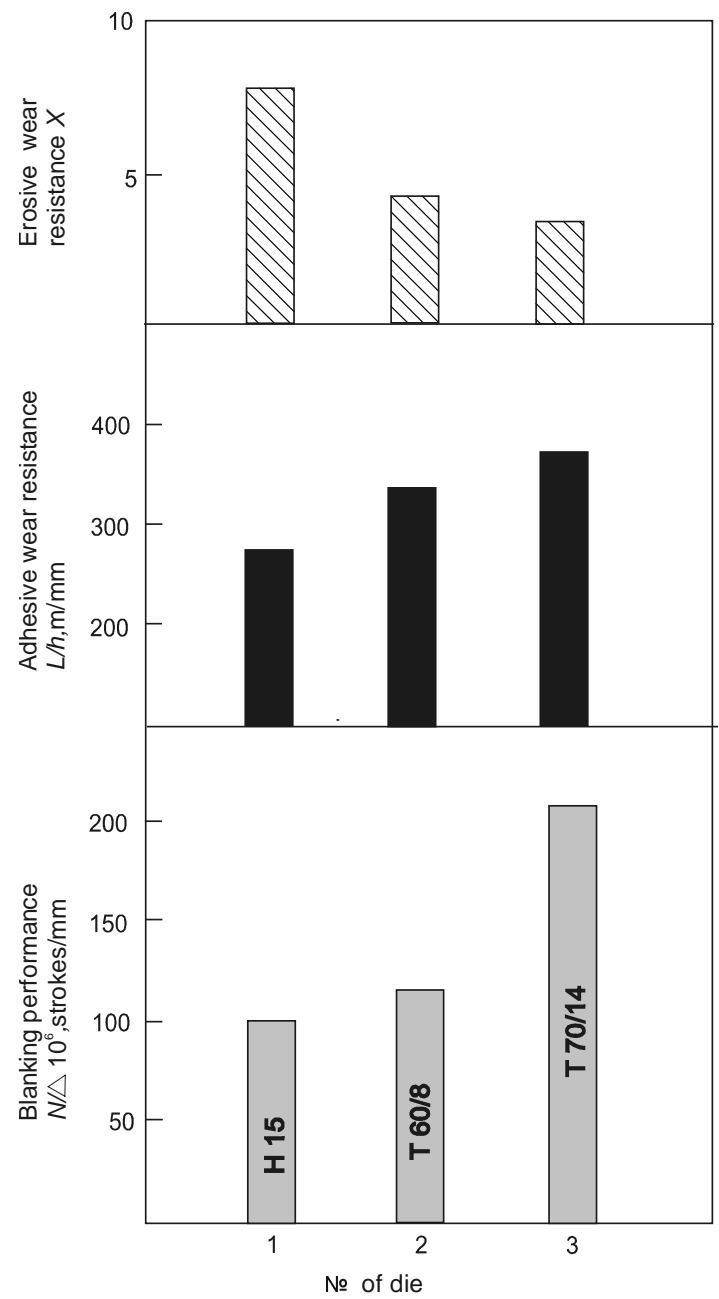

Fig. 2. Wear resistance and blanking performance of cemented carbides. 


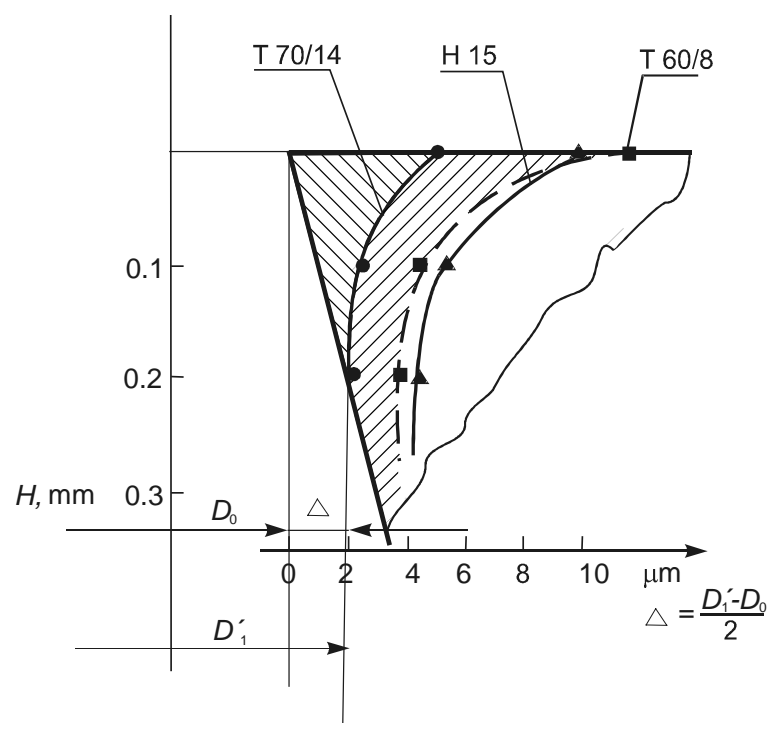

Fig. 3. Wear contours and side wear $\Delta$ of different cemented carbides (blanking tools).

The values of durability characteristics relevant for metalforming of these cermets, hardness, proof stress, and applied toughness, were close to those of the conventional WC-15Co hardmetal used as optimal for blanking and other metalforming operations.

In terms of abrasive-erosion wear resistance both TiC-base cermets, as expected, have a considerable disadvantage relative to the WC-hardmetal. As stated previously, the abrasive-erosion wear resistance of carbide composites depends primarily on the properties (strength and rigidity) of the carbide phase and less on those of the binder (its proof stress) $\left.{ }^{3,8}\right]$. Results of the experiments demonstrate the superiority of titanium carbide base cermets over the WChardmetal from the point of view of the adhesive wear resistance $L / h$. This confirms that the adhesive wear resistance of carbide composites (in contrast to abrasion wear) depends primarily on the properties of the binder and less on those of the carbide phase.

Results of functional wear tests conducted in blanking of grooves into sheet steel are presented in Fig. 3. It must be noted that during testing of the die (3-position die reinforced with cermets to be investigated) neither fracture nor brittle chipping of cutting edges could be detected. The results, wear contours of cutting edges and side wear $\Delta$ of the dies (Fig. 3) demonstrate the obvious superiority of TiC cermet T70/14 over WC-base hardmetal.

In general it may be stated that between the blanking performance of carbide composites (tested as tool materials in blanking operations) and their adhesive wear resistance a fair correlation exists (Fig. 2).

Our results are also confirmed by the results of the SEM analysis of worn surfaces of hardmetal blanking tools. Scanning electromicrographs of both worn 
surfaces, of the blanking tool and of the adhesion-test specimen, were compared. As a result, these were found similar: in both cases, the failure (removal of the material) started primarily in the binder phase (Figs. $4 a, b$ ). After removal of the binder, the worn areas in the microstructure act as failure initiating stress concentrators inducing acceleration of wear, i.e., cracking carbide grains and removing them (and their conglomerates "carbide + binder") in the process of loosing the protective binder layer (ensuring favourable compression stresses in carbides resulting in the improvement of their resistance to failure). In the last step, the removed carbides may act as abrasive particles.

Briefly, the hardmetal wear resistance in blanking is controlled by the adhesive wear resistance of the binder (by its resistance to adhesion interaction and to removal).

The blanking performance of the cermet T60/8 (consisting of $60 \mathrm{wt} \% \mathrm{TiC}$ and a Ni8 steel binder with martensite-bainite microstructure), although characterized by adhesive wear resistance close to that of the cermet T70/14, was markedly lower. It did not exceed that of the conventional WC-hardmetal.

The investigation of worn surfaces (near the cutting edges of blanking tools) by SEM revealed some differences in the micromechanism of wear (Fig. 5). The SEM image of the worn alloy T70/14 showed that uniform wear had prevailed. Microcracks were not observed. In the microstructure of a conventional WC-hardmetal, as well as in the microstructure of TiC-cermet T60/8, microcracks near the cutting edges were observed. Origination of microcracks may be considered as a result of fatigue (local microfailure caused by repeated blanking forces).

Formation of the local microfailure results in microchipping of cutting edges during blanking (Fig. 6). Microchipping of cutting edges causes increase in shearing forces, which results in the acceleration of the side wear $\left[{ }^{3,4}\right]$.
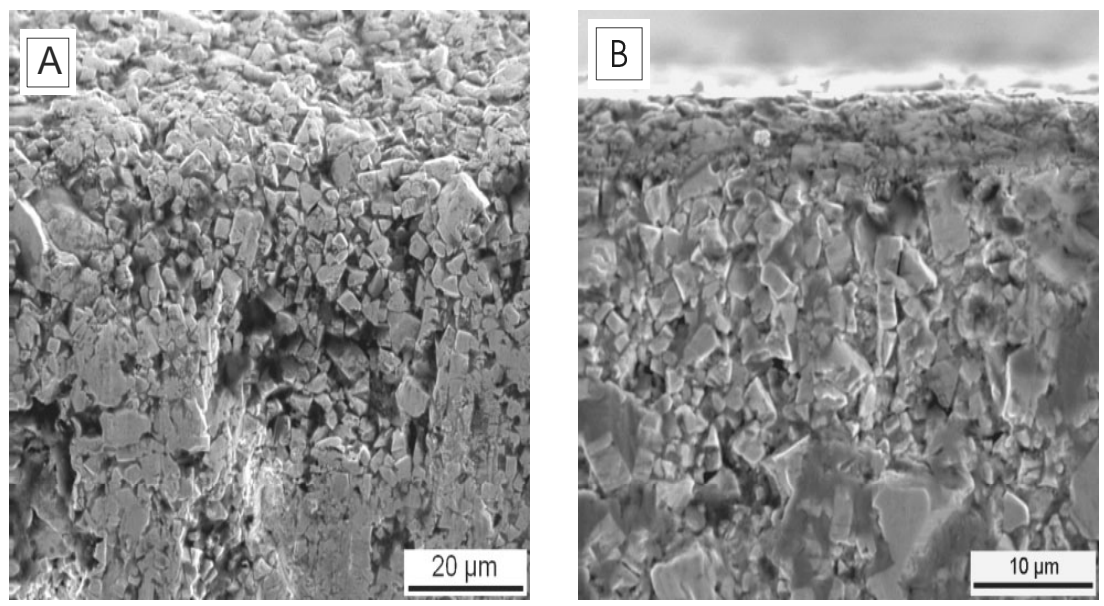

Fig. 4. SEM image of hardmetal surface worn during blanking ( $N=5 \times 10^{5}$ strokes) (A) and during adhesive wear testing (B). 


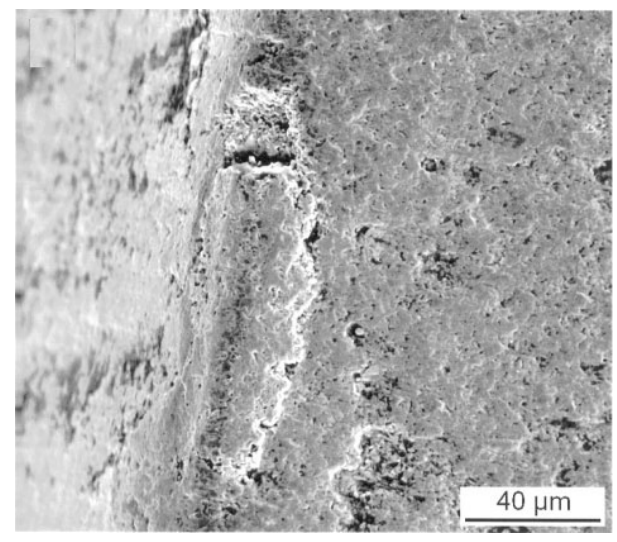

Fig. 5. SEM image of hardmetal H15 worn surface (close to the cutting edge of the blanking tool) representing origin of microcracks $\left(N=3 \times 10^{5}\right.$ strokes $)$.

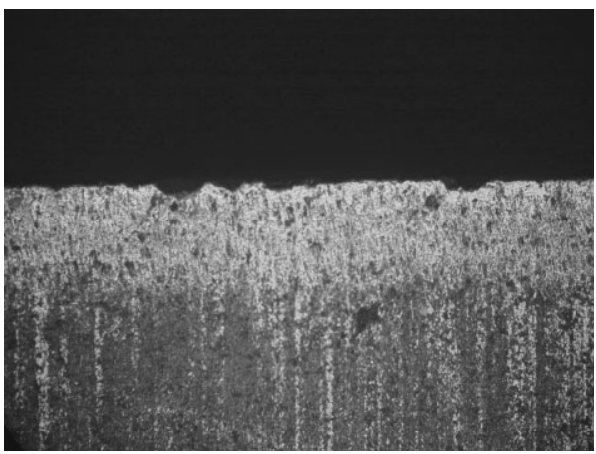

Fig. 6. Microchipping of the hardmetal-tool (H15) cutting edge (after $5 \times 10^{5}$ strokes).

Thus the advantage of TiC-base cermet T70/14 (its higher blanking performance) over the conventional WC-hardmetal may be related first to the higher adhesive wear resistance of its $\mathrm{Ni}$-steel binder (compared with Co-binder) and secondly, to its higher resistance to microcrack formation during repeating loads (fatigue damage).

In Fig. 7 results of fatigue tests, the Wöhler curves of cermet T70/14 and conventional WC-hardmetal $\mathrm{H} 15$, are presented. In general they confirm the results

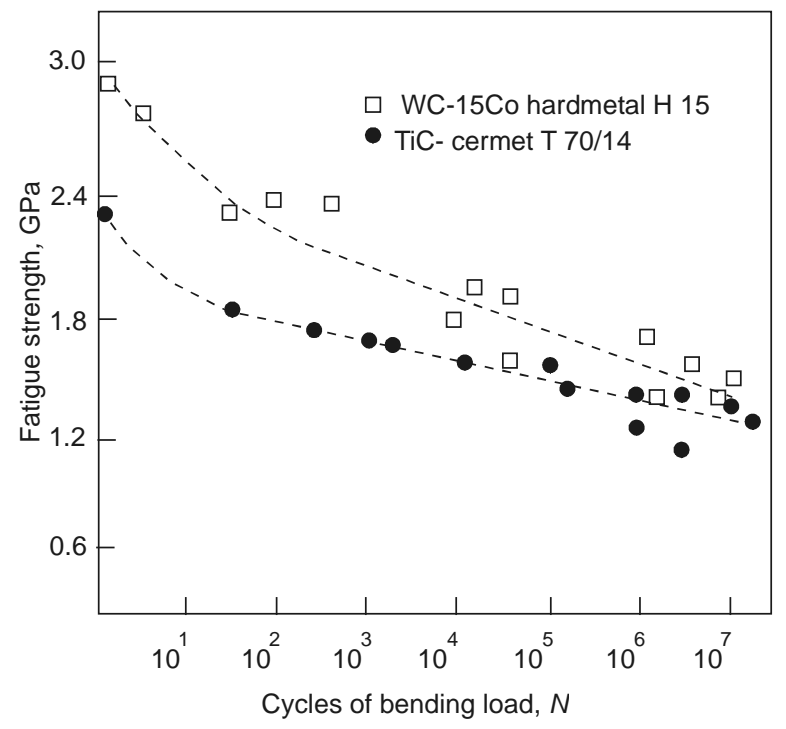

Fig. 7. Wöhler curves of cemented carbides: 1 - hardmetal H15; 2 - TiC-cermet T70/14. 
of SEM investigations. The higher resistance of TiC-cermet T70/14 (compared to H15) to the start and propagation of fatigue cracks (fatigue damage) may be related to its lower fatigue sensitivity (lower intensity in decrease of strength with the increase of loading cycles) featured by the slope of the Wöhler curve.

In a previous paper $\left[{ }^{9}\right]$ it has been shown that resistance of cemented carbides to fatigue damage (the fatigue sensitivity) is related to a great extent to their ability to absorb fracture energy (elastic strain energy storing at crack tips during repeated loading) by means of local plastic strain (origin of plastic zones at crack tips) $\left[{ }^{10}\right]$. Briefly, the fatigue damage is to a great extent controlled by plasticity (ultimate plastic strain) of the cemented carbide. In Table 1 it can be seen that plasticity $\varepsilon_{\mathrm{p}}$ of the TiC-cermet is higher than that of the hardmetal H15 and cermet $\mathrm{T} 60 / 8$.

\section{CONCLUSIONS}

Based on the results of blanking, fatigue, and wear tests, the following conclusions may be drawn.

1. A fair correlation between the wear of cemented carbides during blanking (side wear of the blanking tool) and their adhesive wear resistance has been revealed.

2. The blanking performance of cemented carbides is controlled firstly by their adhesive wear resistance (in particular of the binder) and secondly by their resistance to the appearance and propagation of microcracks during repeated loads (fatigue damage).

3. The superiority in blanking performance of the advanced TiC-base cermet over the conventional WC-base hardmetal is related to the higher adhesive wear resistance of its Ni-steel binder (compared to the Co binder) and its higher resistance to the fatigue damage.

4. The resistance to fatigue damage of carbide composites is characterized by their fatigue sensitivity (by the slope of Wöhler curve) and is related to a great extent to the ability of the cermet to obtain plastic deformations.

\section{ACKNOWLEDGEMENT}

This study was supported by Estonian Science Foundation (grant No. 4850).

\section{REFERENCES}

1. Brookes, K. J. World Dictionary and Handbook of Hardmetals and Hard Materials. International Carbide Data, London, 1996.

2. Eigi, R., Viktorov, G., Reshetnyak, H. (Klaasen, H.), and Talkop, A. Hardmetal Dies in Electrotechnical Machinery. Energoizdat, Moscow, 1988 (in Russian). 
3. Klaasen, H. and Kübarsepp, J. Properties of hardmetals influencing their wear in sheet metal blanking. Tribologia, 2001, 20, 20-30.

4. Reshetnyak, H. and Kübarsepp, J. Resistance of hardmetals to fracture. Powder Metall., 1998, 41, 211-216.

5. Schleinkofer, U., Sockel, H. G., Görting, K., and Heinrich, W. Fatigue of hard metals and cermets - new results and better understanding. Int. J. Refr. Met. Hard Mater., 1997, 15, $103-113$.

6. Errico, G., Bugliosi, S., and Calzavarini, R. Wear of advanced ceramics for tool materials. Wear, 1999, 225-229, 267-272.

7. Sheikh-Ahmad, J. Y. and Bailey, J. The wear characteristics of some cemented tungsten carbides in machining particle board. Wear, 1999, 225-229, 256-266.

8. Kübarsepp, J., Klaasen, H., and Pirso, J. Behaviour of TiC-base cermets in different wear conditions. Wear, 2001, 249, 229-234.

9. Klaasen, H., Kübarsepp, J., and Preis, I. Toughness of carbide composites and their durability in application. In Proc. European Conference on Hard Materials and Diamond Tooling EURO'PM2002'. Lausanne, 2002, 240-246.

10. Exner, H. E. Understanding the toughness and strength of WC-Co hardmetals. In Proc. 1996 European Conference on Advances in Hard Materials Production. Stockholm, 1996, 255 262.

\title{
TiC-baasil valmistatud kõrgtehnoloogiliste kermiste vastupidavus
}

\author{
Heinrich Klaasen, Jakob Kübarsepp ja Irina Preis
}

Töös on vaatluse all metallide survetöötlemisel perspektiivsete TiC- ja WCkarbiidi baasil valmistatud kõrgtehnoloogiliste kermiste mehaanilised ja kulumisomadused. On analüüsitud erineva koostise ja sideaine struktuuriga kermiste vastupidavust kulumisele ja väsimusele stantsimisel. On selgitatud, et kermiste vastupanu stantsimisel on määratud nende adhesioonkulumiskindluse ja väsimustundlikkusega. Võrreldes traditsiooniliste WC-karbiidi baasil valmistatud kõvasulamitega on $\mathrm{TiC}$ baasil valmistatud teras-sideainega kermistel eeliseid metallide survetöötlusel. 